\title{
Federalism and Euro-Regions in Europe: What Have We Learned From Twenty-Five Years of Cross-Border Cooperation in the Euro-region of Galicia-North Portugal?*
}

\author{
Argimiro Rojo Salgado, Enrique José Varela Álvarez \\ University of Vigo, Pontevedra, Spain
}

\begin{abstract}
The present paper is focused on the analysis of the European building processes from the historical perspective of federalism (from ethnic federalism to current federalism) applied to the current framework of Europeanization and cross-border cooperation in Europe. With the objective of reviewing some of its processes and impacts, an analysis structure has been set, being the main purpose to extract conclusions on the long Europeanization process undertaken by the EU institutions. One of these recent processes reached the consolidation of Euroregions as cross-border cooperation institutions within the framework of multilevel governance. For the main purpose of the paper, the following questions are raised: How has the perspective of federalism contributed to the building of cross-border institutions, namely Euroregions? After three decades of implementation of the formal cooperation in Europe through institutions as the Euroregions, can it be confirmed that the Euroregions are consolidated as an institutional benchmark within the cross-border cooperation in Europe (CBC-E)? In order to answer these questions, a review of the historic perspective of ethnic federalism applied to the classical models of formal cooperation was undertaken. From this historical revision, the development of the Euroregion within the EU will be analyzed. Finally, the present paper is focused on the case study of the cross-border space that are the Autonomous Region of Galician and the Região Norte de Portugal, as well as its most important cooperative institution, the Euro-region Galicia-North Portugal.
\end{abstract}

Keywords: European integration, ethnic federalism, cross-border cooperation, Euro-regions, Galicia-North Portugal

\section{Introduction}

The present study is focused on the analysis of the European integration processes from the historical perspective of federalism (from ethnic federalism to the current federalism), applied to the present framework of Europeanization and cross-border cooperation in Europe (from now onwards CBC-E).

To review these processes and impacts, an analysis structure has been created with the purpose of drawing conclusions from the long process of Europeanization, undertaken by the European Union institutions. One of these processes has consolidated the Euroregions as cross-border cooperation institutions within the framework

\footnotetext{
* Paper developed by the authors within the framework of the research project: "Cross-border cooperation and deborderization: Stakeholders and Transnational Geopolitics Discourses in the Spanish-Portuguese Border". (CSO2012-34677), funded by the Ministry of Economy and Competitiveness (Government of Spain).

Argimiro Rojo Salgado, School of Social Sciences and Comunication, University of Vigo, Pontevedra, Spain.

Enrique José Varela Álvarez, School of Social Sciences and Comunication, University of Vigo, Pontevedra, Spain.
} 
of multilevel governance.

For the purpose of this paper, the following research questions have been raised: (1) How has the perspective of federalism contributed to the construction of cross-border institutions, particularly for the Euroregions? (2) After three decades of implementation of the formal cooperation development model in Europe, through institutions as the Euroregions, can it be confirmed that these are consolidated as an institutional benchmark within the field of CBC-E?

In order to answer these questions, first of all an historic review of the ethnic federalism perspective applied to the classic models of formal cooperation is carried out. This perspective sought to reflect on the real integration of the peripheral areas within the territories of the State nations that were shaping what is today known as the European Union. From this historic review, the development of the Euroregions within the EU will be analyzed, as innovative sub-national institutions of formal cross-border cooperation that contributed to fostering regional development and cohesion policies together with the rest of the local and state institutional stakeholders for the last 25 years in Europe. Finally, the case study is the cross-border area that constitutes the autonomous region of Galicia and the Região Norte of Portugal, as well as its most relevant institution, the Euroregion Galicia-North Portugal.

After 25 years of development of formal cross-border cooperation (Varela, 2013, pp. 329-356), the theoretical proposal derives from the need to reflect on "other" processes of integration-reunification, other institutions, formal-informal and material-immaterial that are taking place in the European scenario, in its meaning, consequences and its long term reach (Varela, 2015, pp. 49-69). These consequences revolve not only around the implementation of new proposals and fulfillments of formal and material cooperation but also around other different proposals with informal and immaterial character, beyond the classical institutionalized forms (Varela, Cordaland, \& Cancela, 2015, pp. 77-95; Varela, 2015, pp. 49-69). As a result of the "spillover" effect $^{1}$ that the state and the cooperation institutions suffer due to the social and economical crisis that begun in Europe at the beginning of 2008, the border processes are opened to multilevel governance and cross-border governance (Hooghe \& Marks, 2000 y 2004, pp. 15-30; Peña, 2007, pp. 1-18; Varela, 2010; Aguilar, 2013, pp. 103-115), restoring the approaches and previsions formulated in due time by the doctrinal school of thought of the ethnic federalism (Héraud, de Rougemont, Marc, Fouéré, among others). In order to analyze the problem is applied the New Institutionalism approach (Bulmer, 1993, pp. 351-380; Steinmo, 2013, pp. 131-151; Fernández, 2006, pp. 1-25) that will provide institutional consistency to a variety of initiatives that were launched in previous decades (for example, Euregion in the 1950's) but would be consolidated after, from 1990 and from the "Europeanization" process of structures and public policies (Benz \& Eberlein, 1999, pp. 329-348; Featherstone, 2003, pp. 3-26; Radaelli, 2003, pp. 27-56). The New institutionalism review achieves the updating of the proposals, previsions and conjectures of the Euroregional process, that some consider the starting point of a new and unstoppable inclusive sociopolitical dynamic based on the paradigm of multilevel governance (Piattoni, 2009, pp. 1-46). Conclusively, a policy window (Kingdon, 1995) that can lead to the restructuration of the territory and to the configuration of a new political map in Europe and, why not, even to its foundation based in a more human cooperation and collaboration practices (Rojo \& Varela, 2011, pp. 1-30).

\footnotetext{
1 This idea, applied to the European integration and inspired by Jean Monnet consisted in advancing to the federation or union, emerging from institutional proceedings where the state sovereignty would be pooled. Through a process that by its own functional logic, would expand the need of enlarging the spaces of European integration as new government agents would be involved and the public policies would have new needs.
} 


\section{Europe: Old and New Integration, Old and New Borders}

Characterizing Europe through the analysis of its border territories and its sociopolitical communities, now cross-border communities, requires a great exercise of conceptualization and multilevel understanding due to the institutional sophistication, the public policies and the management of community funds that the EU has mobilized within the scope of community territorial cooperation, at least for the last 25 years (Reitel \& Wassenberg, 2015, pp. 1-170).

The challenge is even greater if the proposed analysis is of the local reality (subnational) and of the stakeholders that coexist in the cross-border territories. Hence the need to frame the old and the new integration, old and new borders.

In addition to the previous data, we find processes of "borderization" and "deborderization" (Cairo \& Lois, 2011, pp. 11-22), as "round trips" even in consolidated international spaces such as in the case of the EU. Since its post-war origins, the process of European integration reports cases of building interior borders, as well as segregation due to the fall of the Berlin Wall. Simultaneously, there are other cases based on the elimination of barriers for the mobility of goods and people, driven by community initiatives and the cohesion and regional development policies.

In the European case this fact is particularly conspicuous due to the existence of multiple borders that have been changing along the years, breaking and tearing apart, in many cases, human communities and geographical areas with profound resemblances and a shared history (Ruggie, 1993, pp. 139-174).

The classic "barrier effect" that takes place in the border territories (Gauchon \& Huissoud, 2013) implies a perception of the negative consequences of the mentioned effects ${ }^{2}$. In some cases, this perception provokes and activates a subnational mobilization in favor of overcoming these borders and the following stage of approach, reunion and cooperation results in the "territory effect" (Gauchon \& Huissoud, 2013). This is why the first attempts at cross-border cooperation experiences will mainly have their origins in regions or local entities that are stigmatized by the fact of being a border and will benefit from the existing favorable conditions in the process of European integration, from cohesion and regional development policies and also from community initiatives. However, and as previously mentioned, these processes will be characterized by asymmetry and discontinuity, being subject to the mentioned changes and practices of "borderization" and "deborderization", according to the different border territories and the historic period. Accordingly, at the present time it is appropriate to speak about the "interface effect" (Gauchon \& Huissoud, 2013), that results in the generation of institutional, social and economic inputs and outputs in the cross-border spaces and helps to configure a specific moment in the history of European integration, for which some claim a new narrative (Dujardin, 2014, pp. 235-237).

In the specific case of Europe after World War II, and taking advantage of the excellent policy window (Kingdon, 1995) that was the integration process, in addition to the States, classic stakeholders of the supranational cooperation, i.e. the regional and local stakeholders, subnational representatives of many border areas, will be the ones that will start implementing formal and informal initiatives in order to try to eliminate all of the factors that contributed towards dividing populations and territories on both sides of the border. The regional-local governments will be the main promoters of the $\mathrm{CBC}$-E processes, creating what could be seen as

\footnotetext{
${ }^{2}$ Among other consequences, the transformation of the border landscapes in depressed peripheral areas with important structural deficiencies where the respective state institutions foster a culture based on fear, mistrust and rejection of the other, making the possibility of contact and formal interdependency more difficult.
} 
a spontaneous cooperation from the bottom-up approach, with their main purpose being the improvement of living conditions among their respective populations. Thus, the first CBC-E experiences emerge achieving a great growth from the 1990s until today (Durá, Oliveras, \& Perkmann, 2010, pp. 21-40). The model of the Euroregions as a space and framework of cross-border cooperation is a paradigmatic case in the world (Perkmann, 2008, pp. 253-266).

In order to understand the CBC-E as object of study, is convenient to review the historic context and the academic debate with the aim of understanding and even apply to the present time some of its conclusions. In doing so, the following sections will develop an analysis of one of the theoretical approaches with major contributions to European integration: federalism. In this particular case, the reflections have its origins in the supporters of ethnic federalism that, in the past decades, presented the social bases and the politics about the real integration of the peripheral areas in the territories of the nation-states that form today the current European Union.

\section{Learning From The Experience of a Federal Europe, Natural Regions and the Rediscovered Unity}

The interest in rethinking the proposals of the ethnic federalists has the specific purpose of applying them to the current models of formal cross-border cooperation, such as those derived from cohesion policies and EU initiatives. In this regard, we understand that their postulates and reflections place the peripheral areas of the nation-states within the set of political communities. This is what some authors denominate European integration $^{3}$, due to the analysis of the Europeanization process (Benz \& Eberlein, 1999, pp. 329-348).

To follow the federalist postulates and bind them to the main objective of this paper, the following questions are set out: (a) What did ethnic federalism state about the idea of Europe? (b) what about integration processes? and (c) what can we currently learn about the postulates that support cooperation in formal and material aspects, such as those carried out through the Euroregions?

It is not easy to answer these questions and the future is always unpredictable. Nevertheless, it is necessary to pay attention to this question and to admit that the appearance of new structures such as globalization, supranational integration or the rise of "mesogobierno" (local and regional stakeholders) (Sharpe, 1993) in recent decades are favoring this integration process based on cooperation. In fact, it is slow and insufficient for the ultimate objective of every integration process, particularly if we bear in mind the crisis of the nation-state and its institutions, as well as the systemic crisis that has hit Europe since the end of the last decade (Scott, 2014, pp. 81-93).

Thus, with the aim of answering these questions, we present the main idea of this proposal around the building of a federal Europe (Cancela, 2001) that would be formed by nation-states as key members as well as by other subnational political-territorial entities, mainly defined by the ethno-cultural and linguistic elements and by their human communities. These are the basis of European integration, the key to building borders from proximity.

\footnotetext{
${ }^{3}$ As it is not the object of theoretical reflections, this paper will not analyze the classical debate between federalists and functionalists (Haas, 1964) as part of the contributions to the process of European integration of, nor the most innovative postulates derived from the debate between new-functionalists and intergovernmentalists. We also skip those that have their origins in the study of the ethnic conflicts between democracy and territoriality, in addition to the groundbreaking postulates relatedto multilevel governance and cross-border governance, even though the latter will appear in this research paper as overcoming the federalist postulates.
} 
Therefore, we consider that the approaches, proposals and previsions held by ethnic federalism decades ago, in addition to be closely related to the particular case of this paper, can contribute to enhance the perspective and comprehension regarding this question, as well as the profound changes that are happening in the European scenario and in other regions of the world.

For the main authors of ethnic federalism such as Guy Héraud, Denis de Rougemont, Fried Esterbauer, Andrea Chiti-Batelli, Sergio Salvi, Alexander Marc or Yann Fouéré, the nation-state would represent the Europe of sovereign powers, of division and confrontation, oppression of minorities and dismemberment of communities and historical territories. Its existence would constitute the main obstacle for the processes of European integration and other processes of reunification and reconstruction of peoples, ethnic groups and territories separated by history (De Rougemont, 1977; Héraud, 1976).

Yann Fouéré (1968) speaks about the inevitable need to build the "third" Europe, the united Europe, the people's Europe or the nation-state Europe. Guy Héraud (1968) refers to the advent of the third stage of integration that represents the "newfound unity" which is difficult to achieve due to the peculiar process of "Europeanization" experienced by the Old Continent through the 20th Century based on two simultaneous movements: centrifugal (obtaining of political autonomy and sub-state regionalization) and centripetal (process of European integration) (p. 63).

According to these authors, the "first" Europe emerged in the Middle ages, where for the first time this sense of unity and supranationality is shown. Its unity was based in the feudal organizational model (federal or confederate) and in a shared culture and belief: Christianity (Europe and Christianity merged). This Europe, whose birth can be situated around the year 800 (coinciding with the coronation of Charlemagne) and would last for centuries, extending itself along the Western Empire and its heir, the Roman-German Empire.

The Renaissance and the Reformation marked the start of an evolution that would finish with the birth of the "second" Europe: the Europe of the sovereign powers, division and confrontation without truce. This Modern Age Europe will be characterized by the raise of new state societies defined by the concentration of power and political sovereignty, as well as for the existence of borders that will be, from now, fixed and impermeable. The 19th Century represents the culmination of the process of building-unification of the national states (Germany, Italy) as well as the process of territorial concentration-centralization of political power, incarnated by the unitary State, centralist and Jacobin inspired.

This "second" Europe, weakened by military conflicts and division, is incapable of competing with other regional or emergent agents and feels the imperious need of recovering the lost unity, starting the transition to the "third" Europe. This happens, always according to the approach of ethnic federalism, after the Second World War and after experimenting the tragic consequences of this military conflict. This transit, supported by the European federalists, will start to materialize after 1951 with the signature of the Constitutive Treaty of the European Coal and Steel Community (ECSC).

Thus, the new Europe emerges, built on the rejection of the past wrong experiences (excess of state sovereignty, excess of nationalism, of militarism and with artificial borders that contravened the nature of things), as well as on its best political and cultural traditions and on the conceptions of freedom, equality and human rights. This Europe will be, as Héraud (1968) said, the Europe of the origins and the rediscovered unity, the federal Europe of ethnic groups and natural regions. As well will be, according to Fouéré (1968), the Europe built of communities of reduced dimensions, the natural size Europe (p. 155).

The logic of these approaches lead to a clear questioning of the previous borders and of the European 
political map in force, leading to a new stage where a re-foundation of Europe would be considered. In the new Europe where the current nation-states, their borders and territorial demarcations (exterior and interior) would be object of a profound restructuring. This would be the consequence of the rigorous application of the ethnic-cultural principle of the right of the peoples to self-determination and the application of certain demands of economic and geographic rationality (Fouéré, 1968). Nowadays, political borders accidentally born from military conflicts and the hegemonic imposition of state powers divide many communities; there are plenty of examples in many borders of the current European states. In the 1960s, for Héraud (1968), the current borders obeyed, in the vast majority of cases, the whims of history, which frequently mutilated ethnic groups, disrupted linguistics and culture and imposed unnatural unions or barriers (p. 32).

According to these approaches, if these divisions were arbitrary, it was necessary to reinterpret them and to adapt them to the authentic natural reality of Europe. Thus, the Europe of the origins would emerge (or reappear), the Europe of the natural communities, true constituent unities of the future European Federation. In this sense, Héraud (1976) proposed the creation of a catalog of communities or natural regions identified by a series of attributes and own characteristics (cultural, linguistic, geographical, historical, economical, demographical, anthropological, etc.), that in many cases would coincide with the old nations and homelands that would now regain their existence. The reorganization of the European territory, the appearance of new demarcations with the resulting new political map, would be the result (p. 56).

Ethnic federalism considered that the process would be long and would need a transition period during which several tasks should be undertaken. First of all, the consolidation of these regional realities and, in parallel, the structure of the Nation-state should be dismantled, as well as the official doctrine and culture that were their legitimate support during their historical existence.

During this stage of territorial and political redefinition and restructuring, the regions would initiate multiple relationships among themselves, creating and strengthening cooperation bonds in different matters, parallel to their process of self-affirmation and consolidation. The outcome, as well as the consequences of this gradual rapprochement process, cooperation, cross-border and interregional integration, would be that anticipated by ethnic federalism, that conclusively suggest an active participation of the regions in the community decision-making process (Rojo, 1996).

From these theoretical postulates and after the boost of cohesion and regional development policies that the European Union initiated at the end of the 1980s, it is possible to confirm the existence of some normative, institutional and financial changes that will help the evolution of the federal model into another, based on multilevel governance. This new framework will provide space for subnational participation, especially for stakeholders that seek institutional consolidation of the cross-border peripheral areas of the exhausted nation-state. The specific formula will be the cross-border cooperation and its tool will be the Euroregion institutions, which will be analyzed hereafter.

\section{Cross-border Cooperation in Europe (CBC-E): The Euroregions as Old-New Space of Formal and Informal Cross-Border Cooperation}

The federal proposals encourage institutional debate from the empowerment and the legitimation of the subnational communities that live in the peripheral areas of the states. This debate should arise through the participation and creation of new institutions that represent and deal with the proposals of the citizens and public stakeholders. 
This theoretical approach is key to understand the motives of the posterior institutional developments during the process of Europeanization (Morata, 2007, pp. 7-39). Without these reflections and its update, the understanding of the Euroregional phenomenon and its different models since the creation of Euregio until today may result confusing.

The Euroregions are a model of subnational and cross-border institutional innovation that is unique in the context of global processes of regional integration. However, they are also the result of the desires of the political communities from the border territories in peripheral areas that wish to improve their income level, employment rate, sustainable development, social cohesion from the co-participation in a multilevel agenda where until the end of the 20th century, the only involved stakeholders were the nation-states.

From the birth of the cross-border cooperation in the North of Europe in the 1950s until the launching of the Interreg community initiatives, in the 1990s, the Euroregions have turned into key agents for the development of many European border spaces. Nevertheless, the integration processes and the cooperation models are not exhausted with the formal and material institutional designs, as showed in the reflections of ethnic federalists and the institutional evolution of the Euroregions. Furthermore, the real regional development framework in Europe continues to be asymmetric, as can be verified in this section of the paper.

If these approaches are followed, it is possible to understand that between the revision of the ethnic federalism approach and the neoinstitutional approaches, it is possible to "reset" (Varela, 2015, pp. 49-69) the new-functionalist approaches of European integration, considered classical after more than five decades of institutional integration in Europe. It confirms the contribution of the regional and local "mesogobiernos" ("non central" stakeholders; Hocking, 2004, pp. 395-426) to various initiatives; political and community programs for cross-border and territorial cooperation that the EU has launched during the last 25 years (1990-2015). Through their postulates it is possible to see the intense evolution of the integration processes, partly due to the European cross-border cooperation (hereinafter, CBC-E) as well as due to the alternatives to the spillover effect that the nation-states have suffered and the center-periphery strategy, initiatives where these new cross-borders areas are framed.

The new forms of multilevel governance, the multilevel dimension of the states, its "liquid" institutional forms (as Euroregions), as well as the production and public consumption logics, private and common, have as a result, the appearance of the regional and local agents (Varela, Cordal, \& Cancela, 2015, pp. 77-95). These are placed in the cross-border scenario actively participating in the cooperation policies and programs, contributing with complementary values to these formal and informal state cooperation practices. At the same time, the initiatives and services that integrate the local and regional agents, closer to the human communities and more receptive to human participation, incorporate to the informal and immaterial dimension the cross-border spaces, where the citizens feel the border spaces as something theirs, as a common good.

These new integration and cross-border cooperation processes in Europe encourage complementary models of relations between national and subnational entities that are fostered through institutional formulas such as "paradiplomacy" (Aldecoa \& Keating, 1999; Paquin, 2004), that conforms what Meltssen (2005) names as "new public diplomacy" (pp. 3-27), a practice through which the local and regional stakeholders, public and private, assume a proactive position, compromised with the local and global network. An example of this new logic of international interaction and cooperation is found in the most recent transformations of European building, where the nation-state barely maintains the original references of their politics and territory (sovereignty, security, international relations and physical borders) and currently are in transition processes 
towards a renewed territorial formula based on a "multiperspectival polity" (Ruggie, 1993, pp. 139-174).

\section{What are the Euroregions and How Important Are They for the CBC-E?}

In the mid-20th Century, the first cross-border cooperation initiatives in Europe took place. These experiences, which can be found in the Nordic countries through so-called "Scandinavian Groups" were constituted after the creation in 1952 of the Nordic Council, consisting of Denmark, Norway, Sweden, Finland and Iceland. Later, in 1962, the Helsingfors Treaty was signed to establish the legal framework, at the same time that the cooperation fields between both parties were defined. Under these agreements, various cooperation experiences would emerge in the area, such as the case of the Oresund Council, Nordkalotten or Kvarken. 1958 saw the creation of the Euregio (Perkmann, 2008, pp. 253-266) during the first cross-border conference, held among associations of municipalities belonging to Enschede (The Netherlands) and Gronau (Germany), with the principle objective of the enhancement of local infrastructures. From 1966 a work group is established, followed by a Secretariat, responsible for organizing the cooperation on both sides of the border. In 1963, the Regio Basiliensis came about, named thus because the city of Basel was the epicenter of the new territorial entity, which was formed by territories belonging to Switzerland, France and Germany and had, as one of its main objectives, the performance of an integration process along the axis of the Rhine (Ricq, 2006).

In the years after, happened other experiences (EuregioRhin-Waa, EuregioRhin-Mosa, Region Ems-Dollar) being the last one, after the positive results, the one that will inspire the recommendation of the Commission on October the 9th, 1981 to launch initiatives related to the cross-border cooperation in Europe. From the nineties on, the CBC-E experimented a spectacular development, influencing more territories and subnational entities, creating different common organization structuresand promoting and coordinating actions on both sides of the border (Perkmann, 2003, pp. 153-171). Only in the decade of the 90's were created in Europe 70 CBC-E structures, opposing the 37 created along the three past decades. The number of cross-border regions (Euroregions or Work Communities) rose from 26 in 1988 to more than 70 in 1999 and in 2006 existed more than 140 cross-border regions among the 46 member states of the Europe Council (Domínguez \& Pires, 2014, 23-47; Reitel \& Wassenberg, 2015).

We consider that the best proof of the intense and general process of CBC-E is found in the high number of materialized experiences, achievements, variety of models and legal instruments to carry out the cooperation and overall, in the creation and articulation of this territorial unit named Euroregion ${ }^{4}$. Through it is expressed and symbolized the completion of this continuous approach process, cooperation and integration. After the precursor stage, once consolidated the cooperation stage, the following step is to walk towards integration, embodied by this territorial unit named generically cross-border region or, in the European case, Euroregion.

Initially designed as an intervention unit, target of the economic programs carried out by the EU at the beginning of the nineties, the Euroregion emerged step by step as one of the multiple typologies of the regional or interterritorial associationism, referring to a cross-border space characterized by territorial contiguity and by the cooperation between parties. From this point of view, the emergence of the Euroregion is clearly linked to the need to create specific stable institutions for the management of the cross-border cooperation, ensuring the

\footnotetext{
${ }^{4}$ The rise of Euroregions comprise all the territory of the continent, beyond the limits of the EU. In the North of Europe and Baltic region is created the Euroregion Baltic (1998), Euroregio Karelia (2000), considered as a cross-border cooperation between the EU and Russia, the Euroregio Helsinki-Tallin (2003); in Central Europe appears the Euroregion Neisse/Nisa/Nysa, the Inn-Salzach-Euroregio (1994), the EuroregioTriRhena (1995), the EuroregioInntal (1998) or the Europaregion Tirol-SüdTirol/Alto Adige-Trentino (1999) and in South Europe and mediterranean emerges the EuroregiónNestos Mesta (1990) or the EuroregiónPirineos-Mediterránea (2004).
} 
continuity over time of those relations.

Within the framework of an ideal scenario, the institutionalization of the border regions constitutes the last stage of a process initiated when all types of relations between citizens and entities are activated on both sides of the border, achieving the consolidation of those relations through stable and formal cooperation. With the creation of the Euroregion, the stage of cooperationis overcome and it becomes possible to define and institutionalize the structure that will allow the administration of cooperation and the advance towards the integration and building of the new cross-border space. In this regard, the Euroregion is, at the same time, a change and a qualitative leap in relation to the conception of the cooperation activities, going from a fragmented, intermittent sector performance to another type of performance which is stable, global and integral; as well as moving from a short to medium term perspective to a long term or even a horizon where the end of the cross-border adventure is not questioned but is considered consolidated and irreversible.

In relation to the theoretical definition of Euroregions, authors as Jean Gabbe (2004) define them using their constituent characteristics (pp. 30-52) ${ }^{5}$. Others as Marcus Perkmann (2008) consider them a new and singular platform and territorial transfer point, capable of generating new stakeholders (cross-border stakeholders), new interdependences and new opportunities (pp. 253-266); a definition that would complete the characteristic features established by the Association of European Border Regions (AEBR) in 2001. Finally, Francesc Morata (2007) raised the need to consider the institutional prerequisites of these figures of CBC-E, with the aim of confirming their reality as both normative and real, and their role as a stakeholder of the cross-border network is as relevant as a state stakeholder (pp. 7-39).

In any case, although is a reality in permanent construction, everything points out that we are attending to the emergence of a new unity and delimited territorial circumscription, of a transnational scope and cross-border vocation. A new territorial, human and organizational entity, constituted by subnational units belonging to two or more states and with the objective of permanence in time. The Euroregion means the appearance of a functional and operative space and as well as a new community through the opening of a creation process of a human, territorial, cross-border and trans-state identity. It could be as well a social and citizen transnational space that will participate and will be the reflection of the emerging European citizenship.

The reality is that these cross-border institutions have been enlarged progressively from one space scope to another, creating not only a new functional and operative space for new units or territorial circumscriptions (Reitel \& Wassenberg, 2015, pp. 1-170), for "other" integration-rapprochement processes inside the European scenario (Rojo, 2010, pp. 12-27), but alsoforanother new identity and social reality. All this is a consequence of the expansive logic of interdependences, "de facto" solidarities and of the own induced effect of state spillover, generator of an increasingly greater integration dynamic. The Euroregional dynamic favors the increasing implication of the different stakeholders on both sides of the border, easing the creation of networks and the generation of shared platforms that could be the embryo of political parties, interest groups (trade unions, industrial organizations, consumer organizations) or social movements (ecologic, feminist, cultural discourse, etc.) integrated in a near future and destined to represent and defend the specific interests of the Euroregional reality within the framework of a plural, polycentric, multilevel Europe ruled by the paradigm of governance

\footnotetext{
5 Territorial areas composed by regional and local collectivities that share a border and that have, as their main objective, to foster cross-border cooperation. They have a different identity than their countries or respective states and have permanent and stable structures with political-administrative, technical and finance resources with internal mechanisms for the decision-making process.
} 
(Bulmer, 1993, pp. 351-380; Perkmann \& Sum, 2002, pp. 3-25; Hooghe \& Marks, 2004, pp. 15-30).

In those cross-border spaces characterized by shared interests, similarities, history or a common feeling of belonging, the integration-cooperation cross-border processes are perceived as a fact and a natural and necessary practice, legitimate and inevitable. A practice aimed to share every initiative that lead to building (or re-building) an integrated territory, creating what we should call historic Euroregions. It is possible to found degrees of homogeneity in, for example, the Euroregions integrated by territories belonging to Germany and The Netherlands, Germany and Denmark, Finland, Sweden and Norway, Ireland and Northern Ireland, Italy and Slovenia, Spain and France (Basque Country-Aquitaine, Catalonia-Languedoc-Roussillon), Spain and Portugal (Galicia and North Portugal), France, Switzerland and Germany, etc.

However, the European Union is aware of the need to enhance the management capabilities of these institutions due to the evolution of the CBC-E programs and the institutional innovations from recent decades. In doing so, legal means are created to support this type of cooperation, first with the signature of international conventions (European Outline Convention on Cross-Border Cooperation, 1980). Later, other technical-legal means appear that are capable of shaping and simplifying cooperation, such as the European Economic Interest Grouping (EEIG) or the European Cooperative Society. These legal structures have their economic nature and their private character in common. Both aspects are an important limitation when managing issues related to CBC-E. In this regard the formula of the European Groupings of Territorial Cooperation (EGTCs; Cancela, Cordal, Domínguez \& Varela, 2012, pp. 61-73), created by Council Regulation 1082/2006 of the European Parliament and the Council of July 5th, 2006. This model also used in existing institutions (Work Communities) and even in other innovative ideas such as Eurocities, Macro-regions, cross-border metropolitan spaces, etc. These new formulas for enhancing cooperation reveal the institutional enlargement that is taking place in the periphery of the States (Reitel \& Wassenberg, 2015, pp. 18-19), and, on the other hand, the asymmetry of the institutional developments and its effects within the framework of multilevel governance (Charron, Lapuente, \& Dykstra, 2014, pp. 68-90; Charron Dijkstra \& Lapuente, 2015, pp. 315-346; European Commission, 2014; European Union, 2015).

These effects produce the need to include in the institutionalized material and formal cooperation theimmaterial and informal practices from the origins of the European border practices, as well as to elaborate a detailed study in each case (Euroregion) with the aim of determining the causes and consequences of the evolution and impacts of the CBC-E in each cross-border territory. The present paper was chosen to analyze, briefly, the case of the Euroregion Galicia-North Portugal with the purpose of exemplifying the processes of cross-border integration and cooperation in the European Union.

\section{Results and Effects of the Cross-Border Cooperation: The Case of the Euroregion Galicia-North Portugal}

The institutional enlargement of the cross-border and territorial cooperation politics and programs have consolidated the model of formal and material cooperation. This model has been based, overall, in the implementation of projects of infrastructures fostered by state and regional agents and, to a lesser extent, by local agents (European Union, 2015).

It is within this framework where the Euroregions acquire their institutional prominence, representing a more complete form of understanding the public problems of the cross-border regions within the inner border of the EU. 
However, the diversity of experiences, the asymmetry of the territories and their territorial, socio-political and economical realities (Domínguez, 2013, pp. 7-35; Salvador, Simões, \& Charles, 2013; Domínguez \& Pires, 2014, pp. 23-47) ${ }^{6}$, and the great difference of the effects on regional development and social cohesion (European Union, 2015) make the application of the institutional analysis to a specific territorial reality necessary. Following the postulates of Flyvbjerg (2004), we propose the study of the Euroregion Galicia-North Portugal as a "paradigmatic case" (pp. 33-62), because is one of the most active community Euroregions and with the most tradition within the cross-border spaces in Spain and Portugal in recentdecades (Domínguez, 2008a, pp. 13-48; 2008b, pp. 51-102). Through these practices, it will be possible to determine with greater precision the emergence of a new model of multilevel governance, cross-border governance (Varela, 2010; Aguilar, 2013, pp. 103-115).

For the verification of this model of analysis were developed the "governance dimensions" established by Aguilar (2014), "institutional dimension" and "technical dimension" (pp. 11-36). The first of these dimensions has been adapted to the case of the Euroregion Galicia-North of Portugal, establishing two levels of analysis that can help its understanding and enhancing the quality of the answers to the research questions: (a) normative development; and (b) institutional development. Thus, different elements of the complex good governance are addressed although other elements related to operative elements were not because they are not objectives of this research.

Regarding the level of normative development, within the institutional development of the analyzed governance, it should be highlighted that Galicia and the North of Portugal are a common space with a two thousand year-old tradition that has developed at the same time as the modern empires and the most recent contemporary nation-state (Medina, 2006, pp. 713-724; López, 1998). Despite all the transformations, this "raiahúmeda" (common name to denominate the border between Galicia and the north of Portugal) can be considered one of the oldest and stable borders of Europe. During the development of the Europeanization process and after the entry of Spain and Portugal to the European Community (1986), the bases for the development of a cross-border cooperation modality were set. There has been progress, setbacks, institutional innovations and good practices in intergovernmental conflict episodes between state stakeholders and subnational stakeholders and even between themselves (regional-local). Obviously, the objective of this competence-collaboration has always been the achievement of more and greater funds for regional development and social cohesion in the border territory, which represents the NUTsII of the Autonomous Community of Galicia and the Região Norte de Portugal.

In this normative scope, there is undeniable progress regarding agreements and cross-border cooperation conventions between territorial entities, signed between the Kingdom of Spain and the Republic of Portugal within the scope of cross-border cooperation (Ministerio de Hacienda y Administraciones Públicas -Ministry of Finance and Public Administrations 2014) ${ }^{7}$. Nevertheless, the base of the Euroregional institutional building

\footnotetext{
6 "In the case of the border between Spain and Portugal, we can observe the polarity of cross-border labor mobility through data from 2008-2010; in fact, the Autonomous Community in Spain with the highest number of Portuguese workers is the border region of Galicia, while the border district of Guarda, in Portugal, receives the lowest number of Spanish workers (Domínguez, 2014).

Domínguez, L. (2014). Asimetrías y puntos de encuentro: la Raya entre España y Portugal (1991-2011). In L. Domínguez (Coord.), Estudio socioeconómico de la frontera entre España y Portugal, Diputación Salamanca, Salamanca, 2013 (p. 33 ). Domínguez and Pires .

7 European Outline Convention on Cross-Border Cooperation within the framework of the Council of Europe (1980), Protocol number 1 (1995) and number 2 (1998), Treaty of Bayonne (1997), Treaty of Valencia (2003), Protocol number 3 of the European Outline Convention on Cross-Border Cooperation (2009).
} 
reveals that the agreements between States do not have the same impact in the different parts of the territory and it should not be forgotten that the Spanish State has three borders: France, Portugal and Morocco. In this sense, and according to the data, over the more than three decades since the European Outline Convention of 1980, of the 69 conventions of cross-border cooperation, 39 have been regarding the Spanish-French border and 30 regarding the Spanish-Portuguese border. Likewise, most part of them have been signed between local and regional entities along the border of Spain-Portugal (15 and 14, respectively), with14 between local entities and 13 joint in the Spanish-French border. This initial data reveals information about the framework where the stakeholders are working and in the long term, these will determine cooperation institutions, strategies and a cross-border action line, as in the Euroregion Galicia-North Portugal.

In the case of the Spanish-Portuguese border, the number of conventions do not help the postulates of tradition, intensity and innovation shown by the indicators of cooperation stakeholders in all the territory of the border (Domínguez, 2008b, pp. 51-102). Galicia stands third in the group of border regions in number of agreements (5, behind Castilla y León with 13 and Extremadura with 6), with the most relevant being the founding treaty of the Galicia-North Portugal Work Community (1991). This treaty set the institutional and management bases for the subsequent Euroregion Galicia-North Portugal as EGTC (European Grouping for Territorial Cooperation) (Reitel \& Wassenberg, 2015, pp. 24-29, 144-147) ${ }^{8}$, as well as the participation of the local stakeholders and its structure and decisions (1999 and 2006). It is clear that the normative framework favors cooperation though not in a direct way, but in hands of subnational stakeholders that must foster the legal means (and even the "alegal" means, without legal entity) in order to encourage the possible acts within the scope of the cross-border cooperation.

If the normative development clears the framework, the institutional development establishes specific rules for every Euroregional space. Within the case study of the Euroregion Galicia-North of Portugal can be revised the intensity of the work of the public stakeholders (to a lesser extent, private) along the last quarter of the century. The works of, among others, Domínguez (2004, pp. 3-51; 2006, pp. 151-185; 2008a, pp. 13-48), Venade (2004, pp. 53-88), Rio, Rojo, Sá, and Varela (2006), Brito (2007, pp. 293-306), Cancela (2008, pp. 157-189; 2010, pp. 67-91), Medeiros (2013, pp. 1249-1266; 2014, pp. 135-154), Rojo (2007, pp. 235-252), Cancela, Cordal, Domínguez and Varela (2012, pp. 61-73), Vieira, Domínguez, Lamas, and Ferreira (2012, pp. 397-412), Varela (2010, pp. 329-356; 2015, pp. 49-69), and Varela, Cordal and Cancela (2015, pp. 77-95), demonstrate the institutional dynamism, including cooperation episodes, complementarities and conflict among all the multilevel public stakeholders, that compete or complement each other to obtain funding from the different European Union budgets.

In this sense, and acknowledging the difficulties still held by cross-border relationships, it should be admitted that after several decades of cooperation, the formal institutional balance in the Euroregion Galicia-North Portugal can be qualified as positive, especially if the great number of ongoing experiences is considered (Reitel \& Wassenberg, 2015, pp. 144-147). To quote only some of the most relevant examples in this Euroregion: a Work Community, diverse European Grouping for Territorial Cooperation (regional and local), city networks (Eixo Atlântico do Noroeste Peninsular-Atlantic Axis of the Northwest Peninsula),

\footnotetext{
8 The constitution of the European Grouping for Territorial Cooperation Galicia-North Portugal (GNP-EGTC) was developed in a process of two years duration (2008-2010) that emerged from the signature of the European Territorial Cooperation Convention between the Xunta de Galicia (Regional Government of Galicia) and the Comissão de Coordenação e Desenvolvimento Regional do Norte (CCDR-N, Commission of Coordination and Regional Development of the North). This process finished in 2010 with the formation of the agreement and the enforcement of the entity.
} 
supralocal networks (Uniminho), Eurocities (Chaves-Verín, Valença-Tuiand Salvaterra do Miño-Monção), centers of higher education (Foundation Center of Euro-regional Studies of Galicia-North Portugal, CEER), multi-functional networks (Red Ibérica de Entidades Transfronterizas, RIET; Iberian Network of Cross-Border Bodies-Domínguez \& Varela, 2015, pp. 225-246), networks of socio-economic stakeholders (Consejo Sindical Interegional Galicia-Norte de Portugal-Interegional Trade-union Council Galicia-North Portugal and Eures Galicia-North Portugal) or the macro-region (Macroregión del Sudoeste Europeo; RESOE-Macro-region of the European Southeast-Bento, 2013).

In this connection, is not possible to deny a reality that shows major transformations in these new scenarios. Where there existed separated institutions and territories is emerging a new vertebrate space, doted of large formal cooperation networks and defined by the density of common initiatives. The experience of the Euroregion Galicia-North Portugal is as well an effective cooperation example due to the achievement of important results, especially visible in the private company collaboration, internal accessibility to the regions through new infrastructures, the enriching common cultural inheritance, the improvement of the natural resources, and scientific and educational cooperation and tourism promotion. The main areas or intervention axis in this new Euroregional space would be related to the cross-border infrastructures (four bridges across the River Miño, logistic platforms) and interregional infrastructures as well (a motorway, a project of a high-speed train). There are plenty of projects regarding economic revitalization (Fondo capital-riesgo Galicia-North Portugal (Risk Capital Fund Galicia-North of Portugal), Centro de Desarrollo, Cooperación y Servicios Empresariales Transfronterizos (Cross-Border Center of Development, Cooperation and Industrial Services), Anuario Estadístico (Stadistical Yearbook), Atlas de empresas (Atlas of companies); research and technologic development (MR Innovación, CTAG/CE11A, Plataforma de desarrollotecnológico del sector del automóvil-Technological development platform of the automotive industry, or Naturplas). Social services are as well an important part of the Euroregion (restoration of villages for the social rehabilitation of underage youth); environment (regeneration of border river basins, creation and joint exploitation of the cross-border park Gêres-Xurés), culture, inheritance and tourism (Fortrans), education, training and employment (Foundation Center of Euroregional studies Galicia-Norte de Portugal, Servicio de Estudios y Publicaciones de la Euroregión Galicia-Norte de Portugal -Service of Research and Publications of the Euroregion Galicia-North Portugal and EixoEcología del EixoAtlàntico Ecological Axis of the Atlantic Axis, EURES Transfronterizo -Cross-Border EURES, FPTRANS, cross-border training for unemployed...).

Is it possible to conclude that this enthusiasm regarding "institutional entrepreneurship", in the words of Perkmann (2002), is a guarantee itself of positive results from the cooperation projects? Is it possible to speak about an active policy style of implementation for community policies and programs (pp. 103-124)? The years of experience among subnational Galician-Portuguese stakeholders show the difficulty of confirming that despite the density and diversity of institutional stakeholders in this part of the Spanish-Portuguese border, the cooperation strategies have resulted from dialogue. Instead, they have been a result of a reactive policy style that has created a dynamic of renouncement to direct institutional conflict but not to the preservation of the "status-quo" and the role of each of the cross-border stakeholders that have been consolidating, for more than two decades, the cooperation between Galicia and the North of Portugal. Only in the last few years, and as a result of the cut in the community funding for the border areas (especially Interreg), there has been a slight change of strategy that has led some of the most relevant stakeholders to arrange the Plan de Inversión 
Conjunta de la Euroregión Galicia-Norte de Portugal (2014-2020) ${ }^{9}$, to develop multifunctional networks (RIET) that can enhance its lobby capacities before their respective states and the European Commission (Domínguez \& Varela, 2015, pp. 225-246).

As can be confirmed from the analysis of the previous levels of the institutional dimension of cross-border governance, the excess of conventions or more institutional stakeholders does not achieve stable frameworks, reinforced cooperation or good complementarities to manage community programing regarding cross-border cooperation. There is a "hidden dimension of management", in words of Agranoffand McGuire (1999, pp. 352-369), that does not appear at plenary sessions in the cooperation institutions and that draws a map of competency and intergovernmental conflicts between stakeholders of each of the territories (Varela, 2010, pp. 338-429). In the end, these are strategies of a "sum of variables", as well as "zero-sum" for the whole of the cross-border cooperation for the Euroregion Galicia-North Portugal, limiting the potential of their capacities. Some authors, including Rojo or Piettoni, call for a change of method, from federalism to governance (Rojo, 2005, pp. 5-30; Piattoni, 2009, pp. 1-46).

\section{Conclusions: After 25 Years of Euroregional Development, What Have We Learned About Cross-Border Cooperation in Europe?}

At the end of the analysis of the process of European integration during recent decades, after reviewing and adapting one of the different approaches, in the case of ethnic federalism and its application to the reality of the cross-border cooperation in Europe using as a case-study the Euroregion Galicia-North Portugal, it is possible to confirm the consolidation of institutional learning. Therefore, the review of the postulates of ethnic federalism helps us to go back to the cross-border sub processes. These were shaped as interactions that already took place before the institutionalization of the CBC-E (beginning of the 1990s). This allows identification of interdependencies and cooperation practices that are the origin of the current institutional practices and were developed by social and political communities on both sides of the borders of the member states. The reviewing of these CBC-E practices helps us to observe the heterogeneity of the cross-border institutional "galaxy" that has a prominent position in the Euroregions. In summary, the paradigm of multilevel-governance informs us about the most recent cross-border governance.

Without any doubt, the great Europeanization process channeled through the financing efforts of the community programming for the last three decades frames a series of cross-border sub processes that arise from historic traditions based on the secular relationship of the different European states.

Therefore, reviewing the postulates of the ethnic federalism helps us to go back to the cross-border sub processes. These were shaped as interactions that already had place before the institutionalization of the CBC-E (beginning of the 1990s). This allows the identification of interdependencies and cooperation practices that are the origin of the current institutional practices that were developed by the social and political communities on both sides of the borders of the member states. The reviewing of these CBC-E practices helps us to observe the heterogeneity hot fix of the cross-border institutional "galaxy" that in has a prominent position in the Euroregions. Definitely, the paradigm of multilevel-governance informs us about all, about the most recent cross-border governance.

\footnotetext{
${ }^{9}$ Document approved by the Xunta de Galicia (Regional Government of Galicia) and the Comissão de Coordenação e Desenvolvimento Regional do Norte (Coordination and Regional Development of the North of Portugal)and the Eixo Atlântico do Noroeste Peninsular (Atlantic Axis of the Northwest Peninsula) in 2014.
} 
Nevertheless, not all learning is positive for the whole of the stakeholders with the responsibility of enhancing the living conditions of the citizens in a multilevel system such as the European system. In fact, this community institutional innovation that is denominated Euroregions, has a series of unresolved territorial, socioeconomic and political-administrative challenges that the European crisis has only increased.

Euroregions are, sometimes, a political and administrative expression (depending on the cross-border state member) of the peripheral institutional power, which represents, largely, the regions and to a lesser extent, the local governments. In addition, this is one of the reasons why after 25 years of CBC-E what is consolidated is a trail of diverse asymmetries in the peripheral areas of the member States. Even though it is true that in some territories more than another, as the case of the previously mentioned differences between the Galician and the Portuguese part in the Euroregion Galicia-North of Portugal.

When looking at the present scenario, 25 years after the beginning of the biggest cross-border cooperation program in the world (Interreg) is possible to confirm that: (1) The normative effort and the institutional development within the CBC-E allow the consolidation of stakeholders such as Euroregions, where the example of Galicia-North Portugal is a paradigmatic case for the border of Spain-Portugal; (2) This consolidation is the result of an institutional evolution process that is very dynamic, that adapts to the community financial framework, to the territorial cooperation initiatives (1990-1993; 2014-2020), as well as to the number of state stakeholders and subnational stakeholders that participate; (3) It is true that despite the enormous financial investment, the socioeconomic asymmetries among peripheral areas in the European Union exist and, in some cases, have intensified due to the 2008 economic crisis; and (4) Along these lines, currently, the Euroregion Galicia-North Portugal is institutionally overwhelmed with the entry of other stakeholders (local and socioeconomic), the addition of other territories (macro-regions) and the replacement of the classic cooperation agenda by a new "second generation" agenda which is reinforced, diverse and informal, that could be named the governance agenda.

To summerize, decades of CBC-E and millions of Euros later, the balance on territorial cooperation in Europe does not allow confirmation of the correlation between institutionalism and effectiveness of the cooperation (Reitel \& Wassenberg, 2015, p. 160). This affirmation allows us to consider the need for a different in-depth institutional plan, based on good governance and in parallel, based on the development of citizen empowerment with the aim of legitimating the European project through the cross-border cooperation.

In this sense, the Euroregions and the approach of multilevel governance could be an institutional, political and administrative advantage for peripheral territories of the European Union and make their regions, citizens, villages and neighbors to participate in the idea of Europe, its projects and contribute to the common welfare (Piattoni, 2009, p. 37). Without question, the great challenge of the European Union for the coming decades.

\section{References}

Agranoff, R., \& McGuire, M. (1999). Expanding intergovernmental management's hidden dimensions. The American Review of Public Administration, 29(4), 352-369.

Aguilar, L. F. (2014). Las dimisiones y los niveles de gobernanza. Cuadernos de Gobierno y Administración Pública, 1(1), 11-36.

Aguilar, L. F. (2013). Gobernanza Transfronteriza: Una Observación Conceptual. In R. Barajas \& L. F. Aguilar (Coords.), Interdependencia, cooperación, gobernanza y fronteras: ¿cuál es el eslabón perdido? (pp. 103-115). Tijuana, Baja California, Colegio de la Frontera Norte.

Aldecoa, F., \& Keating, M. (Dirs.) (1999). Paradiplomacy in action: The foreign relations of subnational governments. London, UK, Frank Cass Publishers. 
Bento, R. (2013). Agenda Estratégica dos Territórios da Fronteira Interior/Transmontana. Porto, Eixo Atlântico do Noroeste Peninsular.

Benz, A., \& Eberlein, B. (1999). The europeanisation of regional policies: Patterns of multi-level governance. Journal of European Public Policy, 2, 329-348.

Brito, W. (2007). As novas tendências da cooperaçãotransfronteiriça entre a Galiza e o Norte de Portugal. In R. García \& L. Lobo (Coords.), España y Portugal. Veinte años de integración europea (pp. 293-306). Santiago de Compostela, Tórculo Edicións.

Bulmer, S. J. (1993). The governance of the European Union: A new institutionalist approach. Journal of European Public Policy, 13(4), 351-380.

Cairo, H., \& Lois, M. (2011). Desfronterización y refronterización en la Península Ibérica. Geopolítica(s), 1, 11-22.

Cancela, C. (2010). Galicia y la Región Norte de Portugal: de la Comunidade de Traballo a la Agrupación Europea de Cooperación Territorial. In J. L. de Castro, F. Letamendía \& F. Morata (Coords.), Cooperación Transfronteriza Comparada: Cataluña, Galicia, País Vasco (pp. 67-91). Bilbao: Gobierno Vasco-Universidad País Vasco.

Cancela, C. (2008). Una nueva fase en la cooperación transfronteriza Galicia-Norte de Portugal. Las Agrupaciones Europeas de Cooperación Territorial. In C. Cancela (Coord.), Cooperación transfronteriza: comparando las experiencias ibéricas (pp. 157-189). Santiago de Compostela: Tórculo.

Cancela, C. (2001). El proceso de constitucionalización de la Unión Europea. De Roma a Niza. Santiago de Compostela: Universidade de Santiago de Compostela.

Cancela, C., Cordal, C., Domínguez, L., \& Varela, E. J. (2012). The "formal" and "informal" cross-border cooperation in Europe. In I. Pires (Comp.), Borders and borderlands: Today's challenges and tomorrow's prospects. Proceedings of the Association for Borderlands Studies Lisbon Conference (pp. 61-73). Lisbon: Centro de Estudos Geográficos.

Charron, N., Dijkstra, L., \& Lapuente, V. (2015). Mapping the regional divide in Europe: A measure for assessing quality of government in 206 European regions. Social Indicators Research, 122(2), 315-346.

Charron, N., Dijkstra, L., \& Lapuente, V. (2014). Regional governance matters: Quality of government within European Union Member States". Regional Studies, 48(1), 68-90.

De Rougemont, D. (1977). Lettreouverte aux Européens. Paris: Albin Michel.

Domínguez, L., \& Varela, E. J. (2015). Construyendo Europolis a partir de la cooperación local «informal» en los espacios transfronterizos de Europa: el caso de la RIET. Geopolítica(s). Revista de estudios sobre espacio y poder, 6(2), 225-246.

Domínguez, L., \& Pires, I. (2014). EU cross-border cooperation. Historical balance and future perspectives. In L. Domínguez, \& I. Pires (Eds.), Cross-border cooperation structures in Europe. Learning from the past to the future (pp. 23-47). Brussels: P.I.E. Peter Lang.

Domínguez, L. (2013). Asimetrías y puntos de encuentro: la Raya entre España y Portugal (1991-2011). In L. Domínguez (Coord.), Estudio socioeconómico de la frontera entre España y Portugal (pp. 7-35). Salamanca: Diputación Salamanca.

Domínguez, L. (2008a). La cooperación transfronteriza entre Portugal y España (1990-2006). Las estructuras de cooperación. In L. Domínguez (Dir.), A CooperaçãoTransfronteiriça entre Portugal e Espanha (pp. 13-48). Porto: EixoAtlântico do Noroeste Peninsular e Instituto Financeiro para o Desenvolvimento Regional, IP.

Domínguez, L. (2008b). Anexos. In L. Domínguez (Dir.), A CooperaçãoTransfronteiriça entre Portugal e Espanha (pp. 51-102) Vigo: EixoAtlântico do Noroeste Peninsular e Instituto Financeiro para o Desenvolvimento Regional, IP.

Domínguez, L. (2006). Cinquenta anos cooperando entre fronteiras na Europa (1950-2000). In L. Domínguez (Dir.), Europa e a CooperaçãoTransfronteiriça (pp. 151-185). Porto: EixoAtlântico do Noroeste Peninsular.

Domínguez, L. (2004). Europa e a Fronteira Luso-Galaica: História e Reencontro. In L. Domínguez \& N. Venade (Coords.), As Euro-Regiões e o Futuro da Europa: O Modelo da Euro-RegiãoGaliza-Norte de Portugal (pp. 3-51). Porto: EixoAtlântico do Noroeste Peninsular.

Dujardin, P. (2014). Reinventing Europe: The eternal quest for a narrative. In E. Batista \& N. Setari (Eds), The mind and body of Europe: A new narrative (pp. 235-237). Brussels: European Union.

Durá, A., Oliveras, X., \& Perkmann, M. (2010). Las regiones transfronterizas: Balance de la regionalización de la cooperación transfronteriza en Europa (1958-2007). Documents d'Anàlisi Geogràfica, 56(1), 21-40.

European Commission. (2014). Investment for jobs and growth. Promoting development and good governance in Eu regions and cities. Sixth report on economic, social and territorial cohesion. Brussels: Directorate-General for Regional and Urban Policy.

European Communities. (2002). Transeuropean cooperation between territorial authorities. New challenges and future steps necessary to improve cooperation. Luxembourg: Office for Official Publications of the European Communities.

European Union. (2015). Eurostat regional yearbook 2015. Luxembourg; Publications Office of the European Union. 
Featherstone, K. (2003). Introduction: In the Name of "Europe". In K. Featherstone \& C. M. Radaelli (Eds), The politics of Europeanization (pp. 3-26). Oxford: Oxford University Press.

Fernández, A. M. (2006). El neoinstitucionalismo como instrumento de análisis del proceso de integración europea. InstitutUniversitariD'EstudisEuropeus, 46, 1-25.

Flyvbjerg, B. (2004). Cinco malentendidos acerca de la investigación mediante los estudios de caso. Revista Española de Investigaciones Sociológicas, 106(04), 33-62.

Fouéré, Y. (1968). L'Europeaux cent drapeaux. Paris: Pressesd'Europe.

Gabbe, J. (2004). The Euroregion as a place for transfrontier cooperation implementation. Quarterly of International Sociology Cooperation and Euroregions, 3-4, 30-52.

Gauchon, P., \& Huissoud, J. M. (2013). Las 100 palabras de la geopolítica. Madrid: Ediciones Akal.

Haas, E. B. (1964). Beyond de nation-State: Functionalism and international organization. Stanford: Stanford University Press.

Héraud, G. (1968). Les principes du fédéralisme et la Fédération européenne. Niza: Pressesd'Europe.

Héraud, G. (1976). L'Europe des ethnies. Niza: Pressesd'Europe.

Hocking, B. (2004). Patrullar por la "frontera": la condición de actores de los gobiernos no centrales. In F. Morata (Ed.), Gobernanza multinivel en la Unión Europea (pp. 395-426). Valencia: Tirant lo Blanch.

Hooghe, L., \& Marks, G. (2000). Multi-level governance and European integration. Lanham: Rowman y Littlefield Publishers Inc.

Hooghe, L., \& Marks, G. (2004). Contrasting visions of multi-level governance. In I. Bache and M. Flinders (Eds.), Multi-level governance: Inter-disciplinary perspectives (pp. 15-30). Oxford: Oxford University Press.

Kingdon, J. W. (1995). Agendas, alternatives and public policies. London: Longman.

López, Á. X. (1998). A Galicia Irredenta. Vigo: Edicións Xerais.

Medeiros, E. (2014). Cross-border cooperation in Raialbérica. The role of the Interreg in building territorial networks. In L. Domínguez \& I. Pires (Eds.), Cross-border cooperation structures in Europe: Learning from the past to the future (pp. 135-154). Brussels: P. I. E. Peter Lang.

Medeiros, E. (2013). Euro-Meso-Macro: The new regions in Iberian and European Space. Regional Studies, 47(8), $1249-1266$.

Medina, E. (2006). Orígenes históricos y ambigüedad de la frontera hispano-lusa (La Raya). Revista de Estudios Extremeños, 62(2), 713-724.

Meltssen, J. (2005). The new public diplomacy: Between theory and practice. In J. Melissen (Ed.), The new public diplomacy: Soft power in international relations (pp. 3-27). New York: PalgraveMacmillan.

Ministerio de Hacienda y Administraciones Públicas (2014). La cooperación transfronteriza realizada por las entidades territoriales españolas. Madrid: Secretaría de Estado de Administraciones Públicas (Gobierno de España).

Morata, F. (2007). La costruzioneistituzionaledelleEuroregioni. Le Instituzini del Federalismo, Regione e GovernoLocale, 4, 7-39.

Paquin, S. (2004). Paradiplomatie et relationsinternationales: théorie des stratégiesinternationals des régionsface à la mondialisation. Bruxelles: PressesInteruniversitairesEuropéennes.

Piattoni, S. (2009). Multi-level gobernance in the EU. Does it work? In Globalization and Politics: A Conference in Honor of Suzanne Berger (pp. 1-46). Retrieved from https://www.princeton.edu/ smeunier/Piattoni

Peña, S. (2007). Cross-border planning at the US-Mexico border: An institutional approach. Journal of Borderlands Studies, 22(1), $1-18$.

Perkmann, M. (2008). Construction of new territorial scales: A framework and case study of EUREGIO cross border region. Regional Studies, 41(2), 253-266.

Perkmann, M. (2003). Cross-border regions in Europe: Significance and drivers of regional cross-border co-operation. European Urban and Regional Studies, 10, 153-171.

Perkmann, M. (2002). Euroregions: Institutional entrepreneurship in the European Union. In M. Perkmann \& N. L. Sum (Eds.), Globalization, regionalization and cross-border regions (pp. 103-124). Basingstoke: Palgrave Macmillan.

Perkmann, M, \& Sum, N-L. (2002). Globalization, regionalization and cross-border regions: Scales, discourse and governance. In M. Perkmann, \& N. L. Sum (Eds.), Globalization, regionalization and cross-border regions (pp. 3-25). Houndmills (Hampshire)/New York: Palgrave Macmillan.

Radaelli, C. M. (2003). The Europeanization of public policy. In K. Featherstone \& C. M. Radaelli (Eds.), The politics of Europeanization (pp. 27-56). Oxford: Oxford University Press.

Reitel, B., \&Wassenberg, B. (2015). Territorial cooperation in Europe-A historical perspective (pp. 1-170). Brussels: European Commission, Directorate-General for Regional and Urban Policy.

Ricq, Ch. (2006). Handbook of transfrontier cooperation. Geneve: University of Geneva and Consigliod'Europa. 
Rio, J. A., Rojo, A., Sá, T., \& Varela, E. J. (2006). A Gobernanza na Eurorrexión Galicia Norte de Portugal. Porto: Eixo Atlântico do Noroeste Peninsular.

Rojo, A. (2010). El fenómeno transfronterizo y la otra integración europea. In J. L. de Castro, F. Letamendía and F. Morata (Coords.), Cooperación transfronteriza comparada: Cataluña, Galicia, País Vasco (pp. 12-27). Barcelona: IUEE.

Rojo, A. (2007). Percepciones mutuas e imágenes recíprocas: España y Portugal ante el espejo. In R. García \& L. Lobo (Coords.), España y Portugal. Veinte años de integración europea (pp. 235-252). Santiago de Compostela: Tórculo Edicións.

Rojo, A. (1996). El modelo federalista de integración europea. La Europa de los Estados y de las Regiones. Madrid: Dykinson, S.L.

Rojo, A. (2005). La gobernanza: un modelo alternativo de gestionar el conflicto. Revista de Pensamento do EixoAtlântico, 8, 5-30.

Rojo, A., \& Varela, E. J. (2011). Las eurorregiones como motores de la refundación europea: Una aproximación politológica. Razón y Palabra, 74, 1-30.

Ruggie, J. G. (1993). Territoriality and beyond: Problematizing modernity in international relations. International Organization, 47, 139-174.

Salvador, R., Simões, R., \& Charles, D. (2013). Evaluation of the main achievements of cohesion policy programmes and projects over the longer term in 15 selected regions (from 1989-1993 programming period to the present). Norte (Portugal) Case Study. Glasgow: University of Strahclyde.

Scott, J. (2014). From Europhoria to crisis. Cross-border cooperation, Euroregions and cohesion. In L. Domínguez \& I. Pires (Eds.), Cross-border cooperation structures in Europe. Learning from the past to the future Brussels (pp. 81-93). Belgium: P.I.E. Peter Lang.

Sharpe, L. J. (1993). The rise of the Meso Government in Europe. London: Sage.

Steinmo, S. (2013). Institucionalismo histórico. In D. Della Porta \& M. Keating (Eds.), Enfoques y metodologías de las ciencias sociales. Una perspectiva pluralista (pp. 131-151). Madrid: Ediciones Akal.

Varela, E. J. (2013). El ADN de la cooperación transfronteriza, La cooperación informal en la Eurorregión Galicia-Norte de Portugal. In R. Barajas \& L. F. Aguilar (Coords.), Interdependencia, cooperación, gobernanza y fronteras: ¿cuál es el eslabón perdido? (pp. 329-356). Tijuana, Baja California, Colegio de la Frontera Norte.

Varela, E. J. (2010). Gestión pública y gobernanza local en perspectiva comparada. Las políticas públicas de modernización administrativa en los gobiernos locales de Galicia y el Norte de Portugal. Madrid: Universidad Complutense de Madrid, Facultad de Ciencias Políticas y Sociología.

Varela, E. J. (2015). Reseteando la gobernanza transfronteriza: Explorando nuevos "cleavages" cooperativos "formal-informal", “material-inmaterial”. In R. Barajas, N. Oddone \& P. Wong (Eds.), Fronteras y procesos de integración. Experiencias comparadas en regiones transfronterizas, perspectivas teóricas y evidencias empíricas (pp. 49-69). Tijuana, Baja California: Colegio de la Frontera de Norte.

Varela, E. J., Cordal, C., \& Cancela, C. (2015). The consolidation of the Euro-regional territory and its consequences: The case of the Galicia-North of Portugal Euro-Region. The Journal of Territorial and Maritime Studies, 2(1), 77-95.

Venade, N. (2004). Galiza-Norte de Portugal: A Eurorregião Necessária. In L. Domínguez \& N. Venade (Coords.), As Euro-Regiões e o Futuro da Europa: O Modelo da Euro-RegiãoGaliza-Norte de Portugal (pp. 53-88). Porto: EixoAtlântico do Noroeste Peninsular.

Vieira, E., Domínguez, L., Lamas, A., \& Ferreira, P. (2012). A Influência dos Interregnas Regiões Transfronteiriças: A RegiãoFronteiriça da Galiza e do Norte de Portugal. In I. Pires (Comp.), Borders and borderlands: Today's challenges and tomorrow's prospects. Proceedings of the Association for Borderlands Studies Lisbon Conference (pp. 397-412). Lisbon, Portugal: Centro de Estudos Geográficos. 